\title{
THE RŪATOKI VALLEY 'ANTITERRORISM' POLICE RAIDS: LOSING 'HEARTS AND MINDS' IN TE UREWERA
}

\author{
Jeffrey A. Sluka
}

ABSTRACT:

This paper was written in response to being invited to be the guest speaker at the one year commemoration of the 2007 police 'antiterrorism' raids in the Rüatoki Valley, held at the Te Rewarewa marae in the township of Täneatua, located at the base of the Urewera Valley entrance to te Urewera - the Urewera Mountains - the historical home of the Tühoe people. Addressing an audience of Tühoe and their guests, it presents perspectives from political anthropology which I thought would be relevant to their experiences. I describe my research on the conflict in Northern Ireland and relate it to the 'antiterrorism' raids in New Zealand, address the debate about 'terrorists' and 'freedom fighters', and identify how indigenous and ethno-national armed resistance has been misrepresented as 'terrorism'. I provide a critical introduction to the concept of 'terrorism' and the significant criticisms anthropologists (and others) have concerning how it evolved and has been used mainly for the purposes of state propaganda and political control. I argue that the Ruatoki Valley 'antiterrorism' raids can be interpreted as a form of pre-emptive counterinsurgency operation during which acts amounting to state terrorism caused significant 'collateral damage' to innocent members of the community. I conclude that the raids not only failed in their stated aim to protect New Zealand from 'terrorism' but, by losing the 'hearts and minds' of local people, possibly increased the potential for political violence or 'terrorism' in this country. As a reminder of the audience and context for which it was written, it is presented in a slightly unorthodox style.

\section{INTRODUCTION}

On 15 October 2007, New Zealand police swept through a number of locations in New Zealand [but primarily the Rūatoki Valley of the Tūhoe people], dressed in black and full riot gear, carrying machine 
guns and handguns, ostensibly searching for material to support charges under the Terrorism Suppression Act 2002. Following an investigation by the Solicitor General, no charges were brought under this act

(Keenan, 2008).

Guns and laws have arrived to terrify the Tühoe people, their mana motuhake (sovereignty) and that of all Māori

(from October 2007 'Letter to the Motu' from then incarcerated Māori activist-cum-'terror suspect' Tame Iti).

\section{Tēnā koutou katoa!}

I was very pleased to be invited by Tūhoe Hauroa to be the guest speaker at the commemoration of the 2007 police 'antiterrorism' raids on the Ruatoki Valley. I am a political anthropologist, and my research has focused mostly on the conflict in Northern Ireland. There are many similarities between Northern Ireland and Aotearoa/New Zealand; they are both 'bicultural' post-colonial settler societies with a history of conflict between the settler and indigenous communities. The Catholics in Northern Ireland are Irish and the descendants of the natives, and the Protestants are British and the descendants of the Scottish and English settlers who colonised and dominated them. In Northern Ireland, the Catholics are the 'Māori' and the Protestants are the 'Pākehā.'

In July 1999, Tühoe activist Te Kaha drew a parallel between New Zealand and Northern Ireland, and was sensationally quoted in the Evening Post under the front page headline 'Protester predicts violence in NZ,' warning of the development of an 'IRA-type situation in this country unless the Government hands back land and authority taken from Māori last century,' and predicting that 'you will see bombings, and you will see killings in this country soon' (Evening Post, 31 July 1999). This is the sort of action or 'intelligence' the New Zealand Security Intelligence Service (sIs) no doubt relied on as 'evidence' of the subversive intentions or potential of Tühoe activists, which subsequently was used to rationalise defining them as 'terror suspects' and thereby justify the police raids as 'counterterrorism' under the Suppression of Terrorism Act 2002.

In November 2004, an article in the Sunday Star-Times reported that the sis had been involved in spying on and infiltrating Māori organizations ('Spies blow whistle on sis bugging, Sunday Star-Times, 21 November 2004). This probably was not news to Tūhoe, who no doubt take this for granted, but it reminded the rest of us that the sis has always spied on Māori activists and or- 
ganisations, and with hindsight we can see that this intelligence gathering was in preparation for the 'Operation Eight' antiterrorism raids of October 2007. I wanted to mention that, because I have worked in subordinated communities actively resisting state repression and learned to be 'security conscious.' So, here in Tāneatua, I feel a bit like 'coming home' to the culture of terror and resistance, where you have to presume the presence of state spies.

My research in Northern Ireland was on 'hearts and minds' and popular support for the Irish Republican Army (IRA) and Irish National Liberation Army (INLA), and what I found was that the terrible way the army and police treated people had a great deal to do with why so many of them supported or joined these militant or insurgent groups. So when I was asked to speak, I wrote back that recently I have been writing critically about losing 'hearts and minds' in the 'war on terrorism' in Iraq, Afghanistan, and Pakistan, which my research leads me to conclude is a completely wrong approach which we can see being lost before our eyes every day, and is ultimately doomed to failure (Sluka, 2010). I am interested in how civilians are treated in war zones and how this affects their political views. In my research in Belfast, I learned that things like checkpoints; randomly searching people, cars, and houses; and gathering intelligence by checking identities and taking names and particulars, conducted by heavily armed soldiers and/or paramilitary police backed by 'special' (that is, draconian) antiterrorism legislation and powers, are characteristics of military occupation, not 'normal' police activities. From that perspective, the 'antiterrorism' tactics used in the Urewera raids were essentially counterinsurgency rather than police tactics, and exactly the opposite of what one might expect to win 'hearts and minds' of the local people or to retain respect for 'the rule of law.'

Basically, our 'state' (that is, the New Zealand government, police, military, and judicial system) has, uncritically and totally bought the post- ' $9 / 11$ ' demand by the US and UK that everyone adopt the official 'war on terrorism' ideology (or propaganda), and they have essentially militarised policing and moved it towards counterinsurgency methods. The Urewera raids represented not so much a 'police action' as a kind of 'pre-emptive counterinsurgency' strike against what turned out to be an essentially fictional 'terrorist' enemy. Preemptive strikes are, more than coincidentally, one of the basic policies of the 'war on terrorism' doctrine launched by President George W. Bush immediately following the terrorist attacks in the US in 2001. The New Zealand state intelligence services and security forces, apparently, view Tūhoe as essentially 'pre-' or 'potentially' insurgent (i.e. 'separatist'), which is why they continuously spy on them and why counterinsurgency tactics, justified as 'counterterrorism, 
were adopted. Of course, my research, and that of others who work in conflict or war zones, shows that this is not only futile but actively counterproductive. You may catch a few militants or 'terrorists', but you alienate the local people, lose the 'battle for their hearts and minds,' and undermine the state's legitimacy and reinforce that of the resistance. That is, instead of preventing or ending violence it does just the opposite; it generates growing resentment which leads to increasing resistance and a greater likelihood the conflict will escalate into violence.

So the Urewera raids were a terrible mistake which, if anything, increased the threat of political violence or 'terrorism' in this country, and say something pretty disturbing about the nature of our state in New Zealand and its attitudes towards Māori sovereignty or tino rangatiratanga. When the raids occurred and I heard of them on the evening news, I was shocked because they were so obviously politically misguided, morally wrong and fundamentally counterproductive (if not frankly stupid-you would think that after dealing with Māori for over 150 years they would know better by now), and that now my adopted country (New Zealand) appeared to have gone as crazy as my birth country (the US).

\section{NORTHERN IRELAND: TERRORISTS OR FREEDOM FIGHTERS?}

As a political anthropologist, my particular interest over the past twenty-five years has been armed national liberation movements-that is, 'freedom fighters'-and I am one of the few social scientists who has actually done face-toface research with people defined as 'terrorists' in their natural setting. My first book, based on my PhD fieldwork, was an ethnographic study of popular support for the IRA and INLA in Divis Flats, a Catholic-nationalist ghetto on the Falls Road in Belfast (Sluka, 1989). The IRA and InLA were, of course, defined by the British government, their allies - including most so-called 'terrorism experts' - and most of the media as 'terrorists.'

In the late 1970 and early 1980 s, when I was a postgraduate student, the modern idea of 'terrorism' first emerged as an ideological weapon of the New Right driven by the Reagan and Thatcher regimes who, following the Israeli lead in employing the 'terrorism' label against Palestinian militants, adopted the idea of 'terrorism' and 'counterterrorism' as their dominant foreign affairs focus. In the US, the Reagan administration came to office declaring they would dedicate themselves to eliminating the plague of 'international terrorism.' Their public relations system then constructed the myth of the 'international terrorist network/conspiracy', and a series of appropriate demons - an 'Evil Empire' 
including Qaddafi, the PLO, the Sandinistas, Castro, and so on - was presented to the public as Soviet clients. Following the ' $9 / 11$ ' terrorist attacks on the US, Bush simply revived Reagan's antiterrorism policy and rhetoric, replacing the 'Evil Empire' with the 'Axis of Evil', originally naming Iran, Iraq and North Korea, and later adding Cuba, Libya, Syria, Belarus, Zimbabwe and Myanmar.

In the UK, Thatcher adopted a propaganda policy of 'criminalisation' as a counterinsurgency weapon to fight the IRA, under which the war in Northern Ireland was officially defined as 'terrorism,' and the British government claimed that the Republican guerrillas were 'criminals' and 'terrorists' with no legitimate political aims and little popular support, who survived only by terrorising their own community. This psychological warfare ('psy-ops') or propaganda tactic was then adopted by every other state in the world fighting insurgents, particularly Spain in their war against the Basque ETA and various Latin American regimes in their numerous wars with left-wing insurgents.

At that time, as a direct academic response to the development of these American and British policies and largely in support of them, 'terrorism studies' first began to emerge. In reading this developing literature prior to my fieldwork in Belfast, I found that the IRA was invariably identified as one of the leading 'terrorist' groups in the world. This intrigued me, because it was clear that there was great public debate about this issue and that most Catholics in Northern Ireland and millions of Irish-Americans and others around the world were convinced that the IRA were 'freedom fighters' or a legitimate armed national liberation movement.

Thus, I set out in my research to empirically test the British state's claim that the IRA and INLA were illegitimate 'terrorists' and the guerrillas' opposite assertion that they were legitimate 'freedom fighters.' I lived in the lower Falls Road community for nearly a year, and conducted fieldwork based primarily on participant-observation and interviews with 76 families or households. These ethnographic methods allowed me to gain the 'rapport' - that is, the acceptance and trust - of people so that they would feel free to speak openly and honestly about this potentially dangerous topic. In my analysis, I applied the 'hearts and minds' theory of insurgent conflicts which emerged in the 1960s and 1970 s from analysis of the Vietnam and other on-going imperial wars, and found essentially that (1) the IRA and INLA were not 'terrorist' groups but rather part of a legitimate armed national liberation movement; (2) that they had a great deal of popular support in their community; (3) that they did not terrorise or intimidate their own people; and (4) that their primary legitimizing agent and recruiting tool was the state terrorism of the brutal 'dirty war' 
counterinsurgency tactics employed by the British army and paramilitary police in Northern Ireland (see Faligot, 1983 and Dillon, 1999).

I concluded that the IRA and INLA could not be defined as 'terrorists' because they did not fit the objective definition. They did not purposely inflict civilian casualties, which is the primary definition of terrorism. They had wellelaborated, though imperfect, bomb-warning systems which worked fairly effectively to minimize civilian casualties, they had internal codes of conduct which specifically prohibited targeting innocent civilians and provided for sanctions against their 'Volunteers' (as they termed themselves) who violated this ethic, and in their violence they were statistically the most discriminate of the three parties to the war - the Republican guerrillas, the British Security Forces, and the Protestant or Loyalist 'paramilitaries':

\begin{tabular}{l|c|c|c}
\cline { 2 - 4 } & $\begin{array}{c}\text { Security } \\
\text { Forces }\end{array}$ & $\begin{array}{c}\text { Nationalist } \\
\text { Guerrillas }\end{array}$ & $\begin{array}{c}\text { Loyalist } \\
\text { Paramilitaries }\end{array}$ \\
\hline $\begin{array}{l}\text { Civilian Deaths as a percentage } \\
\text { by this agency }\end{array}$ & 54.6 & 37.3 & 90.5 \\
\hline
\end{tabular}

(Source: Irish Information Partnership, cited in Weitzer, 1990)

By the objective definition of terrorism specifically as violence aimed at civilians in order to create fear for political purposes, only the Loyalist death squads in Northern Ireland, over 90\% of whose victims were randomly selected for sectarian assassination based solely on their ethno-religious identity, actually fitted that definition - yet, ironically, they were almost never referred to as 'terrorists' (Sluka, 1999).

In the book that emerged from my fieldwork in Divis Flats (Sluka, 1989), I described in detail the role played by state repression - particularly the military and judicial counterinsurgency apparatus - in the formation of community or popular support for the IRA and INLA. Divis Flats was an impoverished innercity ghetto; a high-rise state housing project, it was one of the main battlegrounds of the war. The residents had, since 1969, lived under British military occupation for eighteen years and been caught in the crossfire between the Republican guerrillas, the state security forces, and Loyalist death squads. The community was reputed to be an IRA fortress and INLA stronghold, and was the scene of some of the worst political violence of the 'troubles', as the war was euphemistically referred to. The entire Falls Road district was under British military occupation. Frequent patrols of heavily armed, combat-ready troops and militarized police passed through on foot and in armoured Landrovers, 
and the entire Divis Flats complex was under constant military surveillance from an army observation post located on top of the tallest building-Divis Tower-and helicopters continuously hovered overhead. While trying to live normal lives in one of the central 'killing fields' of the conflict, the people of Divis Flats had been assassinated by Loyalist death squads and attacked by Protestant mobs; killed and injured by rubber and plastic bullets fired during frequent riots and periods of civil disorder; gassed, harassed, intimidated, arrested, interned, interrogated, tortured, and generally brutalized by policemen at infamous interrogation centres and by British soldiers on their streets; and, in a community where there was no normal policing because the police were viewed as the enemy, some had been beaten up or shot ('kneecapped') by the IRA or INLA as punishment for engaging in antisocial or criminal activities.

The most fundamental lesson of my research on popular support for the IRA and INLA was that they enjoyed a high level of support among the Catholic community as a direct result of the repressive counterinsurgency tactics employed by the British army and police. The Security Forces engaged in too many actions in which entirely innocent people suffered. Too many innocent people were hurt by tear gas or injured or killed by plastic or real bullets fired by the Security Forces; too many innocent people had their homes ransacked in searches, were stopped, questioned, and searched in the streets, and harassed and abused by policemen and British soldiers; and too many innocent people were subjected to judicial repression under draconian 'antiterrorism' legislation that made a mockery of human rights in Northern Ireland. The result was that many people became convinced that violence against the state was politically and morally justified, and support for the IRA and INLA flowed directly from this popular conviction.

I, and other researchers, found that the oppression which resulted from military occupation and aggressive counterinsurgency tactics against civilians was the primary factor that generated support and 'volunteers' for the IRA and InLA (Sluka, 1989 and 1995; Feldman, 1991; White, 1989). The British government and Security Forces made the commonly fatal counterinsurgency mistake; because it was difficult for them to come to grips with the guerrillas themselves, they put the Catholic ghettos under military occupation and applied force and judicial repression - that is state terror - in a highly indiscriminate manner against the population they believed supported the guerrillas. In direct opposition to the intended result of pacification, this served only to alienate them, and this catalyst served to create and continuously reinforce popular support for the IRA and INLA. This became a vicious cycle of state repression and popular resistance, because as support for the guerrillas grew 
as a direct result of the counterinsurgency 'dirty war,' the Security Forces and Loyalist death squads increasingly treated the Catholic population as 'terrorist supporters or sympathisers' who deserved to be repressed. The result was a failed counterinsurgency campaign and a quarter-century of guerrilla warfare in Northern Ireland.

In my research in Northern Ireland, and this has been confirmed by anthropologists who have worked in other zones of insurgency, I found that the main things which alienated popular support from the government and lost the 'hearts and minds' of the civilian population were:

- Civilian casualties.

- Political murder ('extrajudicial' killings).

- Judicial repression (draconian 'antiterrorism' laws, arbitrary and indefinite detention in special prisons, and harsh methods of interrogation including torture).

- Everyday human rights abuses under military occupation (body, home, and vehicle searches, abuse by soldiers on patrol and at checkpoints, etc.).

On the basis of the evidence, it appears that the third and fourth of these - judicial repression and human rights abuses by armed security forces - objectively occurred during the raids in the Ureweras, and there was a dangerous possibility that there could have been violence including deaths. I would like to return to that point in my conclusion.

\section{CRITICAL POLITICAL AND CULTURAL DECONSTRUCTION OF 'TERRORISM'}

Anthropologists working in 'high conflict' areas have studied violence, state terror, and resistance, and written detailed ethnographies of armed indigenous, ethno-national, and religio-national movements frequently described as 'terrorists', and all of these studies have been critical of the characterisation of this violence - which includes most of the armed conflicts in the world today - as 'terrorism' rather than more accurate terms such as guerrilla warfare, insurgency, or 'resistance' (e.g., Zulaika, 1988; Sluka, 1989; Feldman, 1991; Nordstrom and Martin, 1992; and Mahmood, 1996). One of the major flaws in 'antiterrorism' propaganda is the confusion of or failure to distinguish between insurgency and guerrilla warfare on the one hand, and terrorism per se on the other. For example, if insurgency is equated with 'terrorism,' than the patriots who fought the American War of Independence and the partisans who resisted Nazi occupation during World War II would be defined as 'terrorists' not 'freedom fighters' or 'patriots.' The empirical reality of the contemporary 
armed popular movements we have studied has simply not fitted with the 'terrorism' image presented by governments and the mainstream media. In general, anthropologists who have studied and written about terrorism have found that the perspectives produced by governments and their academic and media supporters in what Herman and O'Sullivan (1989) describe as 'the terrorism industry,' and much of what passes for orthodox 'terrorism studies', is often unreliable, invalid, biased and propagandistic, and simply does not fit the grounded reality of the political violence we have studied.

Anthropologists are also more aware than most of the fact that, historically, all the indigenous and other 'nation peoples' who have resisted state conquest and domination have been denounced and vilified by those states as 'savages' and 'terrorists,' when objectively they were not. There is a clear correspondence between the former imperialist ideology of the 'savage' other and the contemporary one of the 'terrorist' other. In recent years since the ' $9 / 11$ ' terrorist attacks in the US, anthropologists have published studies critical of the idea of terrorism and how it is employed politically today (e.g., Zulaika and Douglass, 1996 and Zulaika, 2009).

Political anthropologists like myself are generally sceptical about-and have a strong reticence towards-employing the 'terrorism' label because in practice this has always been a pejorative rather than analytical term and its use has most often represented a powerful form of 'felon-setting' or negative labelling that implies a political judgment about the legitimacy of actors and their actions. One of the most fundamental problems is that the concept of 'terrorism' remains essentially contested, and in practice its use is always highly subjective and politically stigmatising. Not only that, we recognise that in employing the concept of 'terrorism' there is no escaping the ethical and political content of the subject because such 'terrorism studies' provide authoritative judgements about who may legitimately be killed, tortured, rendered or incarcerated by the state in the name of 'counterterrorism.'

Anthropologists have also come to the conclusion that much terrorism research lacks rigorous theories and concepts, is based primarily on secondary information, lacks historical context, is heavily biased towards Western and state-centric perspectives, and considers it taboo to take the subjective experience or perspective of those labelled as 'terrorists' into account. Anthropologists argue that the state-centrism of orthodox 'terrorism studies' ignores the roots or causes of terrorism and the contribution the state makes to creating the conditions in which 'terrorist' action by non-state actors occurs. Orthodox terrorism studies is characterised by an 'aura of moral certainty', and terrorism 
has always been viewed in moral terms, with a strong tendency to characterise 'terrorists' as 'evil.' Anthropologists believe that this discourse of 'evil' is antithetical to scientific inquiry, and have discovered that presenting explanations for the motivation of 'terrorists' is to risk being named as an apologist for them. Finally, anthropologists observe that there is a clear symbiotic relationship between 'terrorism' and 'counterterrorism,' and that 'counterterrorist' interventions by the state, which are primarily of a military and security nature, tend to escalate rather than alleviate levels of perceived threat, actual violence, and alienation of the population.

The most outstanding contemporary anthropological study of terrorism is Zulaika and Douglass's superb critical deconstruction of what they term the 'terrorism myth' in their book Terror and Taboo: The Follies, Fables, and Faces of Terrorism (1996). Zulaika and Douglass show that the idea of 'terrorism' is a cultural construct rather than objective concept, and that it is fuelled by vested interests including academics, the media, filmmakers and novel writers, but mainly a plethora of government agencies, right-wing think tanks, and the multi-billion dollar security industry - what Herman and O'Sullivan (1989) describe as the 'terrorism industry' - for their own purposes. Zulaika and Douglass (1996:4) argue that terrorism as presented by authorities and the media is, in effect, a fiction; that 'regarding terrorism, the brandishing of stark facts goes hand in hand with great leaps in discursive fantasy'. It is not coincidental that this is the fundamental characteristic of propaganda, and they conclude that the hype about terrorism-the 'terrorism scare'-is essentially a powerful political myth with enormous consequences. Zulaika and Douglass (1996) conclude that the concept of terrorism is analytically far more of a hindrance than an aid to understanding political violence.

\section{'TERRORISM’ AS STATE PROPAGANDA}

Today, unfortunately, the objective definition of terrorism is rarely applied by state authorities, their academic supporters in the 'terrorism industry,' or the mass media. Rather, it is much more commonly employed as a propaganda tactic to manipulate public fears for political purposes. Leading academics (e.g., Herman, 1982; Chomsky, 1986; Herman and O'Sullivan, 1989; George, 1991; and Said, 1986, 1988a, 1988b) have argued that contemporary use of the concept of terrorism is a essentially a political myth initiated by the Reagan and Thatcher governments in the 1970s and 1980s, and that the rhetoric of antiterrorism evolved as a major ideological weapon of the New Right. They argue that this is basically a new form of the old 'red scare' of the 1940s-196os, and show that both the old 'red scare' and new 'terrorist scare' which first 
emerged in the 1970s and 1980s, but which we see only now coming to full fruition, were created to serve conservative, elite, or state political ends.

The use of 'red scares' is a classic method of gaining acquiescence for policies the public would otherwise oppose. Chomsky (1988:185) explains how this method has been reformulated as a 'terrorist scare', in order to 'manufacture consent' for morally dubious policies - for example, to justify military intervention in the Third World: 'If the populace can be led to believe that their lives and welfare are threatened by a terrible enemy, then they may accept programs to which they are opposed, as an unfortunate necessity. Critics of the 'global war on terrorism' have also argued that it represents the re-invention of a virtually endless new 'Cold War.' For example, Pilger (2002), among others, has argued that:

We] are being conditioned ... to accept a permanent war footing similar to the paranoia that sustained and prolonged the Cold War. The threat of 'terrorism, some of it real, most of it invented, is the new Red Scare. The parallels are striking. In America in the 1950s, the Red Scare was used to justify the growth of war industries, the suspension of democratic rights, and the silencing of dissidents. That is happening now (also see Chomsky and Pilger 2003).

\section{ARMED CONFLICT AND 'TERRORISM' IN THE WORLD TODAY}

Anthropologists of war and conflict have observed that during the second half of the 2oth century, along with the development of the potential for thermonuclear war, there were two other major changes in the nature of global conflict. First, that civilians rather than combatants emerged as the major victims of political violence; in World War I around $11 \%$ of casualties were civilians, while the proportion has risen in most current conflicts to over $90 \%$ civilian casualties. Second, that war within states rather than between them has emerged as by far the major form of armed conflict or war. In an important study in 1994, political geographer Bernard Nietschmann showed that there were more wars or 'armed conflicts' going on than ever before, and that of the 122 armed conflicts at that time, the vast majority $-79.5 \%$ (97) - were internal wars between states and 'nation-peoples' - that is, indigenous and other national groups. Nietschmann also observed that these internal wars against indigenous and other nation peoples encompass most of the groups accused of being 'terrorists'.

Nietschmann $(1987,1994)$ highlighted that indigenous or nation freedom fighters are always misidentified by the states fighting them as 'terrorists': 
When a state is militarily invaded or economically attacked it may declare war, but when the same thing happens to a nation and it resists, it will be accused of declaring terrorism. By state definition, state combatants conduct war, counterinsurgency, and 'police actions' to maintain law and order; nation combatants practice terrorism. Every nation people that has resisted state invasion has been accused of being terrorists: Karen (all 5 million), Miskitos, Kurds, Palestinians, Basques, Irish, Oromo, Tamils, and so on (1987:15. Emphasis added).

Nietschmann observed that oppressive states fighting internal wars against indigenous or other nation peoples always refer to this as 'counterterrorism, and all try to defeat the nation fighters and crush their civilian support by employing state terrorism or 'dirty war' tactics.

Today, there are dozens of examples of the abuse of the epithet 'terrorism' by applying it to legitimate armed resistance movements, which include every major 'hot spot' of political violence in the world today: The Russian government claims that Chechen rebels are 'terrorists', the Israeli government claims that the PLO and Hamas are 'terrorists', the Chinese government claims that Uigher and Tibetan separatists are 'terrorists', the Indonesian government claims that the Free Papua Movement (OPM) and Free Aceh Movement (GAM) are 'terrorists', the Philippines government claims that the Moro National Liberation Front and New Peoples Army are 'terrorists', the Sri Lanka government claims that the Tamil Tigers (LTTE) are 'terrorists', the Spanish government claims that the Basque ETA are 'terrorists', the Burmese junta claims that the Chin, Karen, Kachin, Mon, Karenni, Shan, Wa, and other indigenous rebels in the highlands are all 'terrorists', the Indian government claims that the indigenous rebels in Kashmir and other regions are 'terrorists,' the Colombian government claims that the FARC guerrillas are 'terrorists', the US claims that the Iraq and Afghan insurgents are 'terrorists' and, unfortunately, we must add here the New Zealand authorities claim that Tühoe activists are 'terrorists.' Because in all these cases many well-informed people might be inclined to believe that the causes are just, these governments have tried to convince the world that their opponents are all terrorists, and to create the impression that the solution need not involve political concessions but merely vicious 'counter-terrorism' campaigns.

RELATIVITY, SUBJECTIVITY, AND TERRORISM

It is important to note the notorious subjectivity of the term 'terrorist', summed 
up in the now familiar cliché that 'one person's terrorist is another person's freedom fighter,' and the obvious but important relativity that those labelled as 'terrorists' do not view themselves that way but rather as patriots, 'freedom fighters' and defenders of their people and values. Subjectivity in assessments of 'terrorism' and 'freedom fighting' is based on judgements about whether particular struggles are legitimate or not. Depending on the perspective taken, those labelled as 'terrorists' have been characterised positively as heroes, patriots, and martyrs, and negatively as villains, criminals, fanatics, savages, and crazies. For most people, including academics, the definition or judgement depends on their point of view: Spartacus and Jesus were terrorists to the Romans; Alexander the Great to half of Europe; David to Goliath; Braveheart and George Washington to the English; Custer to the Sioux and Cheyenne; Geronimo and Red Cloud to American settlers; Abraham Lincoln and General Sherman to the Confederate States of America; Lawrence of Arabia to the Turks; Churchill to the people of Dresden; the Japanese to the residents of Nanking; French, Russian, Yugoslavian, and Polish partisans to the Nazis; and Truman to the people of Hiroshima and Nagasaki. Virtually everyone ever defined as a 'freedom fighter' has been simultaneously vilified as a 'terrorist' or the equivalent by the oppressors they struggled against - and even those who did not employ violence, such as Mahatma Ghandi and the Dalai Lama, have been condemned oxymoronically as 'pacifist terrorists.' While legitimate resistance movements sometimes employ terror tactics, it is usually wrong to portray them as 'evil terrorists' rather than insurgents or freedom fighters.

\section{STATE TERROR IN RŪATOKI VALLEY}

Not surprisingly, following the ' $9 / 11$ ' terrorist attacks and the subsequent US 'war on terrorism' response, every state confronting a popular insurgency or national liberation movement eagerly jumped on the 'war on terrorism' bandwagon, re-branding their domestic opponents as 'terrorists.' Beyond that, even countries like Aotearoa-New Zealand that do not face an insurgency or any realistic threat of political violence, tended to look domestically for political opponents to rebrand as 'terrorists', and that resulted in the antiterrorism raids here in 2007. The government enacted powerful new antiterrorism legislation and 'rebranded' a number of political activists - particularly Tūhoe ones - as 'terrorists.' Thus, on 15 October 2007, the 'global war on terrorism,' launched by the US five years earlier, finally arrived in Aotearoa-New Zealand. From the perspective of the people of Te Urewera, the 'anti-terror' raids were experienced as state terrorism: Dozens of police arrived that morning in force, masked, dressed in black, and heavily armed, including automatic weapons. Entire areas around Rūatoki and Tāneatua were locked down; people were 
prevented from leaving their homes for work; cars were stopped and the occupants instructed at gunpoint to leave their vehicles, where they were searched and photographed; a school bus was boarded and young children frightened on their way to Kōhanga Reo; and breaches of civil rights included detaining people for hours without food or water and without formal charges being laid, subjecting women to intimate body searches, herding people into sheds while property searches were underway, and photographing residents at a roadblock set up at the valley entrance (Keenan, 2008:18-19).

The police commissioner, Howard Broad, justified the 'terror raids', as they became known, as being necessary because a small group of about eight key individuals had been identified as posing a threat to the peace and security of New Zealand. These activists were all arrested. In fact, 'Operation Eight' targeted not just Maori 'radicals' but Pākehā activists of various persuasions. A total of seventeen activists were arrested; four from Wellington, six in Auckland, one in Palmerston North, one in Hamilton, and five in the Bay of Plenty area. The police said that they had been under surveillance for nearly two years, and claimed that some had attended 'terrorist training camps' in Te Urewera, learning about civil insurrection, assassination and napalm bombing, and had purchased 'army replica clothing.' The ringleader of this terrorist group was identified as Tühoe rangatira Tame Iti, who was accused of organising and conducting these camps.

The police operation targeted the entire community and was partly an intelligence-gathering 'trolling' operation - hence it can objectively be viewed as a form of state terror rather than a true police operation. A 'normal' police force is not allowed to conduct such operations, because their operations must be based on evidence and requires that the civil rights of innocent people be respected, and this was not the case during Operation Eight. Whatever police 'evidence' was covertly gathered for the operation under the Suppression of Terrorism Act 2002, never made it to court because on 9 November 2007 the Solicitor General announced that the hundreds of pages of intercepted communications relating to alleged terrorist training camps would not be admissible in court. He found that the antiterrorism act was 'incoherent and unworkable, and could not be applied to those arrested in the so-called 'antiterrorism' raids.

As Moana Jackson has observed, the abuse of human rights that occurred during the raids brought hurt and fear into the lives of innocent people and 'created a legacy of mistrust that will not be easily remedied.' Jackson (2008:1) believes that the most puzzling question is 'why the police got things so wrong, 
and why they chose to act in the way they did', and he concludes that it was partly due to 'the seriously flawed provisions of the 2002 Terrorism Suppression Act, which have more to do with the self-obsessed policy approach of the Bush administration in the United States than they do with the genuine need for this country to be safe from harm.' He also suggests that the most nagging question left from the raids is:

Why the authorities were prepared to permit the police to unleash a dreadful and unwarranted fear in the hearts and minds of innocent people; a fear expressed by a young Tūhoe woman who said in the immediate aftermath of the raids that she had been terrorised. That is a terrible cost to have imposed upon such people, for aims that are unclear and operational decisions which were unwise, unacceptably belligerent, and ultimately racist (Jackson, 2008:1-2).

Nàu te whatu Māori ('from the Maori perspective'), this is nothing new, and many Maori and others saw it as just the latest episode of colonisation in the country. As Jackson (2008:2) has observed:

The colonisation of Māori, as of most other indigenous nations over the last five hundred years, has always been about the dispossession and indeed the terrorising of innocent peoples. It has always been about indigenous people being defined as a threat whenever they have questioned their dispossession or whenever the colonisers wanted to keep them in a position of political powerlessness and economic inequality. The real or perceived 'threat' has always then been met with violence, either through military and paramilitary action or the more subtle but no less violent use of personal, collective and legal denigration. Naming the dispossessed as 'rebels', 'subversives,' 'traitors,' 'savage inferiors,' or 'filthy primitives' has a long and sordid history in which the term 'terrorist' now fits with discomfiting and unwarranted ease.

As Jackson (2008: 6) further notes:

Ruatoki was the only place where the whole community was locked down and barricaded by the police. Rüatoki was the only place where people were forced out of their cars at gunpoint and photographed in breach not just of police procedure but basic human rights. Rūatoki was also the only place where mothers, old people and children were searched and held at gunpoint, sometimes for 
hours, with no pretence at respect and no potential for arrest.

That is why it is very much a Tūhoe story.

Jackson argues that racism was the motive for this, and Vijay Devadas (2008:124) has also argued that racism was an essential element in the 'antiterror' raids not only in the policing techniques employed but also in the immediate media coverage of the event, which he argues 'sought to produce a racialised moral panic around terrorism'. Nearly all of the national and international media coverage presented images of Tame Iti and focused on 'Maori sovereignty activists' or 'Maori separatists' as the main people accused of being terrorists, and the choice of Iti to stand in for the figure of the terrorist effectively racialises the image of terror and symbolically links indigenous activism for sovereignty with terrorism. Devadas (2008:141) concludes that: 'what took place that day was not an exception; the racialised visualisation and policing of terror is a continuation of a longer history of exploitation and oppression of the indigenous community in this country'.

While no doubt racism played its part, to me, the main reason was because it was Tühoe. There is a strong, outspoken strain of what may be termed 'Tūhoe nationalism.' Some Tühoe consider themselves a separate nation because the tribe never signed the Treaty of Waitangi and never ceded sovereignty to the Crown, and Tūhoe activists such as Tame Iti and Te Kaha want confiscated land returned and Tūhoe to be recognised as a country within a country. The New Zealand authorities have always been fearful of Māori acquiring weapons and harbouring thoughts of 'rebellion' (Innes, 2008), and the state apparently views Tühoe as the most rebellious and potentially politically violent community in the country. This underscores Te Kaha's warning in 2004-noted ear-

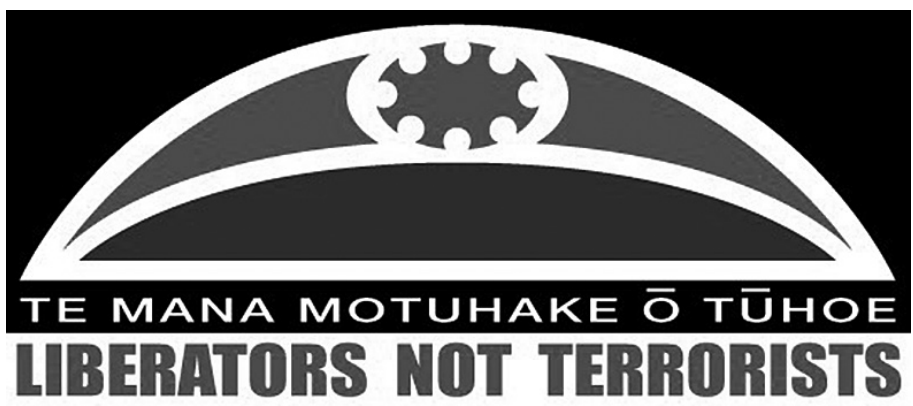

Post-terrorism raids Tūhoe flag bumper sticker 
lier-that there could be "IRA-style attacks" in this country. Because of "Tühoe nationalism, the state intelligence services and security forces, apparently, view Tūhoe as essentially 'pre-' or 'potentially' insurgent (i.e. 'separatist'), hence counterinsurgency tactics, justified as 'counterterrorism,' were adopted.

Jackson (2008) also explores the parallels, from the Māori perspective, between the Suppression of Rebellion Act 1863 and the Terrorism Suppression Act 2002. Both allowed the state to misdefine Māori as either 'rebels' or 'terrorists', prefatory to imposing state sanctioned violence to control them. That is, 'rebel' was and 'terrorist' is the legal definition of someone the state intends to employ violence against. So when you get that label put on you, it's a 'red light' warning of impending state violence against you. In the current political climate of 'terrorism hysteria' (also termed 'terrorism derangement syndrome') labelling people as 'terrorists' is frankly intimidating if not terrifying. Simply doing this represents a form of state intimidation or terrorism, and it is clear that the police 'overstepped their role by utilizing the language of 'terror' to support their activities' (Keenan, 2008: 23).

It is hard to not agree with Nicky Hagar (2007:A11), who has argued that the raids were a 'colossal over reaction; a gigantic terrorism operation where there were no terrorists.' He concludes that the raids were a case of 'poor judgement, preconceived ideas and organisational vested interests' (Hagar, 2007:A11). The antiterrorism police acted on dubious evidence against people they had already decided were terrorists, and this inductive logic was reinforced by 'group think, as New Zealand authorities uncritically adopted the spectacularly unsuccessful American-style 'counter-terrorism' security model.

Aggressive police operations, like those employed during the raids in the Ureweras, conducted by paramilitary police backed by 'special' (a euphemism for draconian) antiterrorism legislation and powers, are characteristic of state terrorism and military occupation. The 'antiterrorism' tactics used in the Urewera raids were essentially counterinsurgency rather than police tactics, and should have been expected to have seriously frightened and angered the local community. The government, having uncritically adopted the 'global war on terrorism' propaganda, unwisely militarised policing and moved it towards counterinsurgency methods, and the raids represented as much a 'pre-emptive counterinsurgency strike' as they did a 'police action.'

In the aftermath of the raids, Tühoe began to refer to the incident as 'Black Monday,' and even the Police Minister, Annette King, seemed to recognise the counterinsurgency-like aspects of the police raids when she used the telling 
expression 'collateral damage' to describe innocent people caught up in them. In response to the raids, Maori Party co-leader Tariana Turia, speaking in Parliament on 14 November 2007, also described and decried the 'collateral damage' of Operation Eight, stating that: 'For the Tühoe nation, Black Monday will be forever etched in their memory as the day police sought to blockade and lockdown an entire community for the arrest of two people' (Turia, 2007).

My research, and that of others who work in conflict or war zones, shows that this is counterproductive because it alienates many people, loses the 'battle for their hearts and minds,' and undermines the legitimacy of the state and reinforces that of the resistance. Instead of preventing or ending violence or 'terrorism,' it tends to do just the opposite; it generates increasing resentment and resistance and a greater likelihood that conflict will escalate into violence. Anthropologists observe that there is a clear symbiotic relationship between 'terrorism' and 'counterterrorism,' and that military and security 'counterterrorist' interventions by the state tend to escalate rather than alleviate levels of perceived threat, actual violence, and alienation of the population. As Hagar (2007:A11) concludes:

Sensible cops should understand the best defence against extremism and political violence is a tolerant, open society and freedom of political actions. Aggressive policing of ordinary healthy protest, heavy-handed intelligence targeting of ordinary people, stormtroopers smashing down doors, machine guns held to people's heads and military-style raids on rural communities are all unforgivably shortsighted.

From my perspective, one of the most important questions raised by the raids in the Ruatoki Valley is that they could, at least theoretically, have provoked rather than prevented not only what Aotearoa/New Zealand did not actually have before this - 'terrorism' - but in the extreme case even civil war. Did the government and judicial and police authorities consider this possibility, and what plans did they have, if any, for what they would do if the situation had exploded in their faces?

It is clear that judicial repression and human rights abuses by paramilitarised police occurred during the Urewera raids, that the local community was frightened and intimidated (that is 'terrorised'), and that there was a dangerous possibility that it could have resulted in violent resistance and even deaths. It is apparent that the police believed that they faced a significant threat which justified their being armed to the teeth - that is, that armed resistance might 
result. Thus, if things had gone as badly as apparently the police believed they might in Rūatoki Valley, and Tūhoe had chosen to actively defend themselves, who knows who or how many may have been wounded or killed-innocent people, 'terror suspects,' or police. And if someone had been killed, especially one of the anonymous, black-clad, 'antiterrorism' constables, or an innocent Tühoe bystander, can you imagine what the result may have been? It is just possible that, had things gone badly, the raids could have caused or provoked an armed response from angry Tühoe. It is certain that the government would have branded this as 'terrorism' and responded with even more massive force, which could have resulted in escalating violence, and today we could have been - as Te Kaha warned - in the middle of an 'IRA-style' conflict or civil war. As a placard carried at a hikoi in Whakatane on 19 October 2007 to protest the 'anti-terror' raids succinctly summarised the Tühoe perspective:

'He taonga te mokopuna

We are not terrorists, we have been terrorised'

REFERENCES:

Chomsky, N. 1988 The Culture of Terrorism. London: Pluto Press.

Chomsky, N. 1986 Pirates and Emperors: International Terrorism in the Real World. Claremont: Black Rose.

Chomsky, N. and Pilger, J. 2003 Towards a New Cold War. New York: New Press.

Devadas, V. 2008 ' 15 October 2007, AOTEAROA: Race, Terror and Sovereignty'. Sites, 5(1):124-151.

Dillon, M. 1999 Dirty War: Covert Strategies and Tactics Used in Political Conflicts. New York: Routledge.

Faligot, R. 1983 British Military Strategy in Ireland: The Kitson Experiment. London: Zed.

Feldman, A. 1991 Formations of Violence: Narratives of the Body and Political Terror in Northern Ireland. Chicago: University of Chicago Press.

George, A. (ed) 1991 Western State Terrorism. Cambridge: Polity. 
Hagar, N. 2007 'NZ Terrorism the Backstory'. Sunday Star Times, 11 November, p. A11.

Herman, E. 1982 The Real Terror Network: Terrorism in Fact and Propaganda. Boston: South End Press.

Herman, E. and O'Sullivan, G. 1989 The 'Terrorism Industry': The Experts and Institutions that Shape our View of Terror. New York: Pantheon.

Innes, C. 2008 'Māori With Guns: Armed Māori and the Early Settler Parliament,' in D. Keenan (ed), Terror in Our Midst? Searching for Terror in Aotearoa New Zealand. Wellington: Huia Publishers: 63-77.

Iti, Tame 2007 'Letter to the Motu.' Accessed 26/11/o7 from http://www.scoop. co.nz/stories/HLo710/Soo401.htm.

Jackson, M. 2008 'Preface - The Constancy of Terror', in D. Keenan (ed) Terror in Our Midst? Searching for Terror in Aotearoa New Zealand. Wellington: Huia Publishers: 1-10.

Keenan, D. 2008 'Introduction - Searching for Terror', in D. Keenan (ed) Terror in Our Midst? Searching for Terror in Aotearoa New Zealand. Wellington: Huia Publishers: $17-33$.

Mahmood, C. 1996 Fighting for Faith and Nation: Dialogues With Sikh Militants. Philadelphia: University of Pennsylvania Press.

Nietschmann, B. 1994 'The Fourth World: Nations Versus States', in G. Demko and W. Wood (eds) Reordering the World: Geopolitical Perspectives on the World. Boulder: Westview Press: 225-242.

Nietschmann, B. 1987 'The Third World War, Cultural Survival Quarterly, 11(3): 1-16.

Nordstrom, C. and Martin, J. (eds) 1992 The Paths to Domination, Resistance, and Terror. Berkeley: University of California Press.

Pilger, J. 2002 'The Colder War', The Mirror, 30 January. Accessed 3/2/o2 from http://www.counterpunch.org/pilgercold.html.

Said, E. 1988a 'Identity, Negation and Violence', New Left Review, 171:46-60. 
Said, E. 1988b 'The Essential Terrorist', in E. Said and C. Hitchens (eds) Blaming the Victims: Spurious Scholarship and the Palestinian Question. London: Verso: 149-159.

Said, E. 1986 'America and Libya', London Review of Books, 8 May, p.3.

Sluka, J. 2010 'Losing Hearts and Minds in the 'War Against Terrorism", in A. Robben (ed) Iraq at a Distance: What Anthropologists Can Teach us About the War. Philadelphia: University of Pennsylvania Press: 106-132.

Sluka, J. 1999 “For God and Ulster': The Culture of Terror and Loyalist Death Squads in Northern Ireland,' in J. Sluka (ed) Death Squad: The Anthropology of State Terror. Philadelphia: University of Pennsylvania Press:127-157.

Sluka, J. 1995 'Domination, Resistance and Political Culture in Northern Ireland's Catholic-Nationalist Ghettos.' Critique of Anthropology, 15(1): 71-102.

Sluka, J. 1989 Hearts and Minds, Water and Fish: Popular Support for the IRA and INLA in a Northern Irish Ghetto. Greenwich, CT: JAI Press.

Turia, T. 2007 'The 'Collateral Damage' of Operation Eight.' Speech made during General Debate in Parliament, 13 November, accessed from 15 November http://www.infonews.co.nz/news.cfm?id=9508.

Weitzer, R. 1990 Transforming Settler Societies: Communal Conflict and Internal Security in Northern Ireland and Zimbabwe. Berkeley: University of California Press.

White, R. 1989 'From Peaceful Protest to Guerrilla War: Micromobilization of the Provisional Irish Republican Army, American Journal of Sociology, 94(6): 1277-1302.

Zulaika, J. 1988 Basque Violence: Metaphor and Sacrament. Reno: University of Nevada Press.

Zulaika, J. 2009 Terrorism: The Self-Fulfilling Prophecy. Chicago: University of Chicago Press.

Zulaika, J. and Douglass, W. 1996 Terror and Taboo: The Follies, Fables, and Faces of Terrorism. New York: Routledge. 